\title{
The geochemical composition of the terrestrial surface (without soils) and comparison with the upper continental crust
}

\author{
Jens Hartmann · Hans H. Dürr • Nils Moosdorf • \\ Michel Meybeck $\cdot$ Stephan Kempe
}

Received: 8 July 2010/ Accepted: 22 December 2010/Published online: 28 January 2011

(C) The Author(s) 2011. This article is published with open access at Springerlink.com

\begin{abstract}
The terrestrial surface, the "skin of the earth", is an important interface for global (geochemical) material fluxes between major reservoirs of the Earth system: continental and oceanic crust, ocean and atmosphere. Because of a lack in knowledge of the geochemical composition of the terrestrial surface, it is not well understood how the geochemical evolution of the Earth's crust is impacted by its properties. Therefore, here a first estimate of the geochemical composition of the terrestrial surface is provided, which can be used for further analysis. The geochemical average compositions of distinct lithological classes are calculated based on a literature review and applied to a global lithological map. Comparison with the bulk composition of the upper continental crust shows that the geochemical composition of the terrestrial surface (below the soil horizons) is significantly different from the
\end{abstract}

Electronic supplementary material The online version of this article (doi:10.1007/s00531-010-0635-x) contains supplementary material, which is available to authorized users.

J. Hartmann $(\bowtie) \cdot$ N. Moosdorf

Institute for Biogeochemistry and Marine Chemistry,

KlimaCampus, University of Hamburg, Bundesstrasse 55,

20146 Hamburg, Germany

e-mail: geo@hattes.de

\section{H. H. Dürr}

Department of Physical Geography, Faculty of Geosciences, Utrecht University, Utrecht, The Netherlands

\section{Meybeck}

UMR 7619 Sisyphe, Université Pierre et Marie Curie (Paris VI), Paris, France

\section{S. Kempe}

Institute for Applied Geosciences,

Darmstadt University of Technology, Darmstadt, Germany assumed average of the upper continental crust. Specifically, the elements $\mathrm{Ca}, \mathrm{S}, \mathrm{C}, \mathrm{Cl}$ and $\mathrm{Mg}$ are enriched at the terrestrial surface, while $\mathrm{Na}$ is depleted (and probably K). Analysis of these results provide further evidence that chemical weathering, chemical alteration of minerals in marine settings, biogeochemical processes (e.g. sulphate reduction in sediments and biomineralization) and evaporite deposition are important for the geochemical composition of the terrestrial surface on geological time scales. The movement of significant amounts of carbonate to the terrestrial surface is identified as the major process for observed Ca-differences. Because abrupt and significant changes of the carbonate abundance on the terrestrial surface are likely influencing $\mathrm{CO}_{2}$-consumption rates by chemical weathering on geological time scales and thus the carbon cycle, refined, spatially resolved analysis is suggested. This should include the recognition of the geochemical composition of the shelf areas, now being below sea level.

Keywords Geochemistry - Terrestrial surface · Continental crust $\cdot$ Lithological map · Major elements

\section{Introduction}

The continental crust constitutes only $0.6 \%$ of the silicate Earth by mass, but its upper layer is the only readily accessible part of our planet and has been the main target of geochemical research. For major elements, geochemical evolution of the Earth's continental crust resulted in a geochemical differentiation between lower and upper crust (Table 1), so that the continental crust itself is vertically stratified in terms of its chemical composition (c.f. reviews of Rudnick and Gao 2003; Hawkesworth and Kemp 2006). 
Table 1 Comparison of chemical compositions (weight- $\%$ ) for major elements (forced to $100 \%$ according to their relative proportion, excluding trace elements and $\mathrm{H}_{2} \mathrm{O}$ )

\begin{tabular}{|c|c|c|c|c|c|c|c|c|c|c|c|c|c|c|c|}
\hline & \multirow{2}{*}{$\begin{array}{c}\text { this study } \\
\begin{array}{c}\text { terrestrial } \\
\text { surface }\end{array}\end{array}$} & \multicolumn{4}{|c|}{ Rudnick \& Gao (2003) } & \multicolumn{4}{|c|}{$\begin{array}{l}\text { relative enrichment/depletion of the terrestrial } \\
\text { surface (TS) compared to crust segments }\end{array}$} & \multicolumn{4}{|c|}{$\begin{array}{l}\text { enrichment/depletion (ED) of the TS relative to } \\
\text { crust segments (CS): ED = (TS - CS) / CS }\end{array}$} & \multicolumn{2}{|c|}{$\begin{array}{l}\text { enrichment/depletion } \\
\text { uncertainty analysis }\end{array}$} \\
\hline & & $\begin{array}{c}\text { upper } \\
\text { continental } \\
\text { crust }\end{array}$ & $\begin{array}{c}\text { middle } \\
\text { continental } \\
\text { crust }\end{array}$ & $\begin{array}{c}\text { lower } \\
\text { continental } \\
\text { crust }\end{array}$ & $\begin{array}{l}\text { average } \\
\text { crust }\end{array}$ & $\begin{array}{c}\text { upper } \\
\text { continental } \\
\text { crust }\end{array}$ & \begin{tabular}{|c|} 
middle \\
continental \\
crust
\end{tabular} & $\begin{array}{c}\text { lower } \\
\text { continental } \\
\text { crust }\end{array}$ & $\begin{array}{l}\text { average } \\
\text { crust }\end{array}$ & $\begin{array}{c}\text { upper } \\
\text { continental } \\
\text { crust }\end{array}$ & $\begin{array}{c}\text { middle } \\
\text { continental } \\
\text { crust }\end{array}$ & \begin{tabular}{|c|} 
lower \\
continental \\
crust
\end{tabular} & $\begin{array}{l}\text { average } \\
\text { crust }\end{array}$ & \begin{tabular}{|l|} 
TS: $+10 \%$ \\
UCC: $-10 \%$
\end{tabular} & $\begin{array}{r}\text { TS: }-10 \% \\
\text { UCC: }+10 \%\end{array}$ \\
\hline Si & 25.60 & 30.98 & 29.62 & 24.94 & 28.23 & - & - & + & 0 & $-17 \%$ & $-14 \%$ & $3 \%$ & $-9 \%$ & $1 \%$ & $-32 \%$ \\
\hline $\mathrm{Ti}$ & 0.36 & 0.38 & 0.41 & $\begin{array}{l}0.49 \\
\end{array}$ & 0.43 & 0 & - & - & - & $-5 \%$ & $-12 \%$ & $-26 \%$ & $-15 \%$ & $17 \%$ & $-22 \%$ \\
\hline $\mathrm{Al}$ & 6.43 & 8.11 & 7.92 & \begin{tabular}{|l|l|}
8.94 \\
\end{tabular} & 8.39 & - & - & - & - & $-21 \%$ & $-19 \%$ & $-28 \%$ & $-23 \%$ & $-3 \%$ & $-35 \%$ \\
\hline $\mathrm{Fe}$ & 3.58 & 3.90 & 4.67 & $\begin{array}{l}6.66 \\
\end{array}$ & 5.19 & 0 & - & -- & -- & $-8 \%$ & $-23 \%$ & $-46 \%$ & $-31 \%$ & $12 \%$ & $-25 \%$ \\
\hline $\mathrm{Mn}$ & 0.065 & 0.077 & 0.077 & \begin{tabular}{l|}
0.077 \\
\end{tabular} & 0.077 & - & - & - & - & $-16 \%$ & $-16 \%$ & $-16 \%$ & $-16 \%$ & $3 \%$ & $-31 \%$ \\
\hline $\mathrm{Mg}$ & 1.77 & 1.49 & 2.16 & \begin{tabular}{l|l|}
4.36 \\
\end{tabular} & 2.80 & + & - & -- & $-\cdots$ & $19 \%$ & $-18 \%$ & $-59 \%$ & $-37 \%$ & $45 \%$ & $-3 \%$ \\
\hline $\mathrm{Ca}$ & 8.15 & 2.55 & 3.74 & 6.85 & 4.56 & ++ & ++ & + & ++ & $219 \%$ & $118 \%$ & $19 \%$ & $79 \%$ & $290 \%$ & $161 \%$ \\
\hline $\mathrm{Na}$ & 1.26 & 2.41 & 2.51 & 1.96 & 2.27 & - & -- & -- & $-\cdots$ & $-48 \%$ & $-50 \%$ & $-36 \%$ & $-44 \%$ & $-36 \%$ & $-57 \%$ \\
\hline $\mathrm{K}$ & 2.09 & 2.30 & 1.90 & 0.50 & 1.49 & 0 & + & ++ & ++ & $-9 \%$ & $10 \%$ & $316 \%$ & $40 \%$ & $11 \%$ & $-26 \%$ \\
\hline$P$ & 0.063 & 0.065 & 0.065 & \begin{tabular}{l|l}
0.044 \\
\end{tabular} & 0.057 & 0 & 0 & ++ & + & $-3 \%$ & $-3 \%$ & $45 \%$ & $12 \%$ & $19 \%$ & $-20 \%$ \\
\hline $\mathrm{S}$ & \begin{tabular}{l|l|}
0.347 \\
\end{tabular} & 0.062 & 0.025 & \begin{tabular}{|l|}
0.034 \\
\end{tabular} & 0.040 & ++ & ++ & ++ & ++ & $461 \%$ & $1296 \%$ & $906 \%$ & 761\% & $586 \%$ & $359 \%$ \\
\hline C & 2.60 & 0.32 & 0.19 & $\begin{array}{l}0.06 \\
\end{array}$ & 0.19 & ++ & ++ & ++ & ++ & $717 \%$ & $1280 \%$ & $4393 \%$ & $1285 \%$ & $899 \%$ & $569 \%$ \\
\hline $\mathrm{Cl}$ & 0.082 & 0.029 & 0.018 & \begin{tabular}{l|l}
0.025 \\
\end{tabular} & 0.024 & ++ & ++ & ++ & ++ & $179 \%$ & $350 \%$ & $227 \%$ & $236 \%$ & $241 \%$ & $129 \%$ \\
\hline 0 & 47.59 & 47.32 & 46.70 & 45.07 & 46.26 & 0 & 0 & 0 & 0 & $1 \%$ & $2 \%$ & $6 \%$ & $3 \%$ & $23 \%$ & $-18 \%$ \\
\hline Sum & 100.00 & 100.00 & 100.00 & 100.00 & 100.00 & & & & & & & & & & \\
\hline \multicolumn{16}{|c|}{ Wedepohl (1995) } \\
\hline Si & 25.60 & 31.08 & & \begin{tabular}{|l|}
27.48 \\
\end{tabular} & & - & & 0 & & $-18 \%$ & & $-7 \%$ & & $1 \%$ & $-33 \%$ \\
\hline $\mathrm{Ti}$ & 0.36 & 0.32 & & \begin{tabular}{l|l}
0.51 \\
\end{tabular} & & + & & - & & $13 \%$ & & $-28 \%$ & & $38 \%$ & $-7 \%$ \\
\hline $\mathrm{Al}$ & 6.43 & 7.93 & & \begin{tabular}{|l|l|}
8.33 \\
\end{tabular} & & - & & - & & $-19 \%$ & & $-23 \%$ & & $-1 \%$ & $-34 \%$ \\
\hline $\mathrm{Fe}$ & 3.58 & 3.16 & & 5.79 & & + & & $\cdots$ & & $13 \%$ & & $-38 \%$ & & $38 \%$ & $-8 \%$ \\
\hline $\mathrm{Mn}$ & 0.065 & 0.05 & & $\begin{array}{l}0.09 \\
\end{array}$ & & + & & - & & $20 \%$ & & $-30 \%$ & & $47 \%$ & $-2 \%$ \\
\hline $\mathrm{Mg}$ & 1.77 & 1.38 & & \begin{tabular}{l|l|}
3.20 \\
\end{tabular} & & $(++)$ & & & & $28 \%$ & & $-45 \%$ & & $57 \%$ & $5 \%$ \\
\hline $\mathrm{Ca}$ & 8.15 & 3.02 & & \begin{tabular}{|l|l|}
4.93 \\
\end{tabular} & & ++ & & ++ & & $170 \%$ & & $65 \%$ & & $230 \%$ & $121 \%$ \\
\hline $\mathrm{Na}$ & 1.26 & 2.63 & & 2.15 & & - & & -- & & $-52 \%$ & & $-41 \%$ & & $-41 \%$ & $-61 \%$ \\
\hline $\mathrm{K}$ & 2.09 & 2.62 & & \begin{tabular}{l|l|}
1.33 \\
\end{tabular} & & - & & ++ & & $-20 \%$ & & $58 \%$ & & $-2 \%$ & $-35 \%$ \\
\hline $\mathrm{P}$ & 0.063 & 0.07 & & 0.09 & & 0 & & + & & $-3 \%$ & & $-27 \%$ & & $19 \%$ & $-20 \%$ \\
\hline$S$ & 0.347 & 0.09 & & 0.04 & & ++ & & ++ & & $266 \%$ & & $711 \%$ & & $347 \%$ & $199 \%$ \\
\hline C & 2.60 & 0.32 & & \begin{tabular}{l|l|}
0.06 \\
\end{tabular} & & ++ & & ++ & & $717 \%$ & & $4404 \%$ & & $899 \%$ & $569 \%$ \\
\hline $\mathrm{Cl}$ & 0.082 & 0.06 & & $\begin{array}{l}0.04 \\
\end{array}$ & & $(++)$ & & ++ & & $28 \%$ & & $101 \%$ & & $57 \%$ & $5 \%$ \\
\hline $\mathrm{O}$ & 47.59 & 47.26 & & 45.96 & & 0 & & 0 & & $1 \%$ & & $4 \%$ & & $23 \%$ & $-18 \%$ \\
\hline Sum & 100.00 & 100.00 & & 100.00 & & & & & & & & & & & \\
\hline \multicolumn{16}{|c|}{ Taylor \& McLennan (1995) } \\
\hline $\mathrm{Si}$ & 25.60 & \begin{tabular}{|l|}
30.80 \\
\end{tabular} & & \begin{tabular}{l|l|}
25.29 \\
\end{tabular} & & - & & 0 & & $-17 \%$ & & $2 \%$ & & $2 \%$ & $-32 \%$ \\
\hline $\mathrm{Ti}$ & 0.36 & 0.30 & & $\begin{array}{l}0.58 \\
\end{array}$ & & + & & - & & $22 \%$ & & $-37 \%$ & & $49 \%$ & $0 \%$ \\
\hline $\mathrm{Al}$ & 6.43 & 8.03 & & \begin{tabular}{|l|l|}
8.49 \\
\end{tabular} & & - & & - & & $-20 \%$ & & $-24 \%$ & & $-2 \%$ & $-34 \%$ \\
\hline $\mathrm{Fe}$ & 3.58 & 3.49 & & \begin{tabular}{|l|l}
8.21 & \\
\end{tabular} & & 0 & & - & & $3 \%$ & & $-56 \%$ & & $26 \%$ & $-16 \%$ \\
\hline $\mathrm{Mn}$ & 0.065 & 0.05 & & 0.17 & & + & & - & & $20 \%$ & & $-62 \%$ & & $47 \%$ & $-2 \%$ \\
\hline $\mathrm{Mg}$ & 1.77 & 1.33 & & \begin{tabular}{|l|l|}
3.77 \\
\end{tabular} & & ++ & & - & & $34 \%$ & & $-53 \%$ & & $64 \%$ & $10 \%$ \\
\hline $\mathrm{Ca}$ & 8.15 & 2.99 & & \begin{tabular}{l|l|}
6.04 \\
\end{tabular} & & ++ & & ++ & & $173 \%$ & & $36 \%$ & & $234 \%$ & $124 \%$ \\
\hline $\mathrm{Na}$ & 1.26 & 2.89 & & \begin{tabular}{l|l|}
2.06 \\
\end{tabular} & & $\cdots$ & & - & & $-56 \%$ & & $-39 \%$ & & $-46 \%$ & $-64 \%$ \\
\hline $\mathrm{K}$ & 2.09 & 2.80 & & \begin{tabular}{l|l}
0.53 \\
\end{tabular} & & - & & ++ & & $-25 \%$ & & $299 \%$ & & $-8 \%$ & $-39 \%$ \\
\hline $\mathrm{P}$ & 0.063 & 0.09 & & & & - & & & & $-27 \%$ & & & & $-11 \%$ & $-40 \%$ \\
\hline $\mathrm{S}$ & 0.347 & & & & & & & & & & & & & & \\
\hline C & 2.60 & & & & & & & & & & & & & & \\
\hline $\mathrm{Cl}$ & 0.082 & & & & & & & & & & & & & & \\
\hline 0 & 47.59 & \begin{tabular}{|l|}
47.23 \\
\end{tabular} & & \begin{tabular}{l|l}
44.87 \\
\end{tabular} & & 0 & & 0 & & $1 \%$ & & $7 \%$ & & $24 \%$ & $-17 \%$ \\
\hline Sum & 100.00 & 100.00 & & \begin{tabular}{l|l}
100.00 \\
\end{tabular} & & & & & & & & & & & \\
\hline
\end{tabular}

Comparison with the Earth crust is based on data compiled by Rudnick and Gao (2003), Wedepohl (1995) and Taylor and McLennan (1995). Crustal data for C are taken from Wedepohl (1969). Deviations of the Earth surface averages from the upper continental crust (UCC) are represented as follows: "O" $=<10 \%$; "+" or "-" $10-30 \%$ deviation " ++ " or "- $->30 \%$ deviation. The last two columns in the table present an uncertainty analysis. The enrichment/depletion of an element at the terrestrial surface is recalculated, applying for a each element a $10 \%$ higher/lower content of the terrestrial surface (TS) composition and a 10\% lower/higher content of the composition of the upper continental crust (UCC)

The upper continental crust is on average granodioritic in composition, and it is assumed to become more and more mafic with depth.

Although the crustal evolution and the processes involved are discussed controversially (e.g. Reymer and Schubert 1984; Rudnick 1995; Albarede 1998; Rudnick and Gao 2003; Hawkesworth and Kemp 2006), major controls of its composition are unanimously identified. These are the differentiation of igneous intracrustal magmas and intraplate crust growth, continent-continent collision (Rudnick and Gao 2003; Hawkesworth and Kemp
2006; Lee et al. 2008), recycling of sediments (Hofmann and White 1982; Plank and Langmuir 1998; Hofmann 2007; Lee et al. 2008), as well as chemical weathering and fluid mass transfer between crust and mantle (Mackenzie and Garrels 1966; Edmond et al. 1979; Albarede and Michard 1986; Rudnick 1995; Lee et al. 2008).

In spite of its obvious importance for the Earth's material cycles, the terrestrial surface composition has not been in a dominant focus of studies on the geochemical evolution of the crust (c.f. Garrels and Mackenzie 1971; Lee et al. 2008), possibly due to the fact that the Earth 
surface layers account for only a small mass proportion of the entire crust. However, knowledge on the geochemical composition and spatial differences of the Earth's surface layers is gaining importance because Earth surface processes (chemical weathering, physical erosion, alteration of minerals and biological activity) impact ocean chemistry, properties of sediment transported to the ocean and the climate system (c.f. West et al. 2005; Berner 2006; Arvidson et al. 2006; Donnadieu et al. 2006).

Geochemical information on the terrestrial Earth surface (which is the upper most accessible part of the continental crust, "the skin of the Earth") can be gained by mapping the surface composition, applying standardized sampling grids and subsequent interpolation between sampled sites. This approach is, e.g. chosen within the European FOREGS programme to establish a geochemical baseline (Imrie et al. 2008). Similar approaches were used to examine the geochemical characteristics of fluvial sediments on the Japanese Archipelago (Imai et al. 2004). However, no such data base exists on the global scale. This 'expensive' approach might neglect that certain and distinguishable lithological units are attributed by comparable geochemical characteristics. Thus, lithological maps might be a good starting point to assess the geochemical composition of the terrestrial surface by applying geochemical information per lithological unit. Note that lithological maps are different from geological maps (Dürr et al. 2005). Typical geological maps provide information on certain rock types like crystalline rocks, which represent about one-third of the Earth's terrestrial surface. They fail, however, to differentiate the other two-thirds that are occupied by sedimentary rocks or unconsolidated sediments (Garrels and Mackenzie 1967; Meybeck 1987; Amiotte-Suchet et al. 2003; Dürr et al. 2005). Dürr et al. (2005) developed a global lithological map, distinguishing lithological classes with the focus on the sensitivity of rocks to chemical and mechanical weathering and their eventual transport by surface waters to the ocean ("hydro"'-oriented lithology).

The "hydro"-oriented lithology approach was chosen because lithology is a key control on river water composition and sediment chemistry, and therefore of land to oceans element fluxes (Meybeck 1987; Bluth and Kump 1994; Gaillardet et al. 1999a, b; Meybeck 2003; Dessert et al. 2003; Oliva et al. 2003; Imai et al. 2004; Lerman et al. 2007; Hartmann 2009; Hartmann and Moosdorf 2010; Hartmann et al. 2010a). Because lithological classifications appear to be a good starting point to evaluate Earth system dynamics with respect to geochemical cycles, it seems to be appropriate to choose a global lithological map where certain representative geochemical signatures are represented by lithological classes. Thus, the global lithological map developed by Dürr et al. (2005) is applied here to estimate the geochemical composition of the terrestrial surface including quaternary sediments (excluding soil layers) and to discern differences with geochemical signatures of the upper continental crust. Geochemical characterization of the terrestrial surface is achieved by translating lithological information into a chemical bulk composition for each lithological class. Processes effective at the global scale and responsible for the geochemical composition of terrestrial surface identified are discussed.

\section{Methodology}

The geochemical characterization of Earth surface rocks has a long history. The earliest compilation identified by the authors has been provided by Justus Roth (Roth 1878, 1879, 1893), including also estimates of geochemical budgets of elements transported from land to the ocean. Further compilations of rock geochemical compositions followed (c.f. and references in: Wedepohl 1969; Garrels and Mackenzie 1971; Le Maitre 1976; Condie 1993; Li 2000; Rudnick and Gao 2003). However, precise estimates of the terrestrial surface composition are still lacking, in part because of the missing combination of spatial geochemical, geological and lithological information. Previous authors used a variety of different rock and geochemical classification schemes, which cannot in every case be directly translated into lithological classes of the applied map. Determining the geochemical composition of the terrestrial surface demands knowledge on the rock-class composition of applied lithological classes. Data of the geochemical composition of the terrestrial surface for comparison with the continental crust have been gained in four steps.

Step 1: calculation of the geochemical composition of typical rock classes

In most models of the composition of the upper continental crust, major-element data are derived from average values for certain rock types based on thousands of samples (mostly surface rocks). For each typically used rock class, an average geochemical composition was assigned here, and data sources used for the compilation of the rock geochemistry in this work are referenced in Table 2. For some elements, no sufficient data could be derived from studies providing averages of large-scale samplings. In this case, further studies, referenced in Table 2, were applied to fill the gaps. However, in case of some crystalline rockclasses, for elements $\mathrm{C}$ and $\mathrm{Cl}$, no sufficient data were available. Thus, the $\mathrm{C}$ and $\mathrm{Cl}$ contents have been assumed to be the same as the average of basalt and granite or similar to basalt, respectively (grey colour background in Table 2). Elemental proportions were normalized to $100 \%$ for better comparison with crustal averages in step 4 . 
Table 2 Geochemical composition of rock classes (weight-\%) applied in this study for calculation of the geochemical composition of lithological classes used in the global lithological map (Ricke
1960; Taylor 1964; Wedepohl 1969; Le Maitre 1976; Taylor et al. 1983; Pfeifer et al. 2000; Li 2000; Max Planck Institute for Chemistry 2006)

\begin{tabular}{|c|c|c|c|c|c|c|c|c|c|c|c|c|c|c|c|c|c|c|c|c|}
\hline Weight \% & 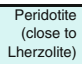 & Gabbro & רodiorite & Granite & Basalt & Andesite & Trachyte & Dacite & Rhyolite & Loess & Sandstones & $\begin{array}{r}\text { Sandstones } \\
\text { from } \\
\text { platforms }\end{array}$ & $\begin{array}{r}\text { Sandstone } \\
\text { Mean }\end{array}$ & \begin{tabular}{|l} 
Shales from \\
'geosynclines'
\end{tabular} & $\begin{array}{r}\text { Shales from } \\
\text { platforms }\end{array}$ & $\begin{array}{r}\text { Shales } \\
\text { Mean }\end{array}$ & Limestones & $\begin{array}{r}\text { Carbonates } \\
\text { from } \\
\text { platforms }\end{array}$ & $\begin{array}{r}\text { Carbonates } \\
\text { Mean }\end{array}$ & $\begin{array}{r}\begin{array}{c}\text { Evaporite } \\
\text { (Halite } \\
\text { Gypsum) }\end{array} \\
\end{array}$ \\
\hline$\overline{\mathrm{SiO}_{2}}$ & 42.43 & 50.34 & 66.07 & 71.20 & 49.11 & 57.71 & 61.05 & 64.76 & 72.70 & 68.45 & 78.64 & 70.22 & 74.28 & 58.74 & 50.48 & \begin{tabular}{|l|}
54.34 \\
\end{tabular} & 6.92 & 8.26 & 7.52 & 0.81 \\
\hline $\mathrm{TiO}_{2}$ & 0.63 & 1.12 & 0.54 & 0.31 & 1.84 & 0.87 & 0.70 & 0.58 & 0.28 & 0.55 & 0.25 & 0.58 & 0.41 & 0.78 & 0.78 & 0.77 & 0.05 & & 0.05 & \\
\hline $\mathrm{Al}_{2} \mathrm{O}_{3}$ & 4.25 & 15.54 & 15.73 & 14.30 & 15.71 & 16.95 & 16.91 & 15.85 & 13.25 & 11.71 & 4.80 & 8.23 & 6.49 & 16.66 & 15.04 & 15.77 & 1.71 & 2.22 & 1.94 & 0.08 \\
\hline $\mathrm{Fe}_{2} \mathrm{O}_{3}$ & 3.62 & 3.02 & 1.38 & 1.21 & 3.78 & 3.26 & 2.98 & 2.42 & 1.48 & 2.73 & 1.10 & 2.51 & 1.80 & 2.79 & 4.38 & 3.57 & 0.98 & 1.01 & 0.99 & 0.19 \\
\hline $\mathrm{FeO}$ & 6.61 & 7.65 & 2.73 & 1.64 & 7.12 & 4.02 & 2.28 & 2.29 & 1.11 & 0.00 & 0.30 & 1.50 & 0.90 & 3.69 & 2.09 & 2.88 & 1.30 & 0.69 & 0.99 & 0.03 \\
\hline $\mathrm{MnO}$ & 0.41 & 0.12 & 0.08 & 0.05 & 0.20 & 0.14 & 0.15 & 0.09 & 0.06 & 0.06 & 0.03 & 0.06 & 0.04 & 0.09 & 0.08 & 0.08 & 0.08 & 0.07 & 0.07 & \\
\hline $\mathrm{MgO}$ & 31.37 & 7.62 & 1.74 & 0.71 & 6.72 & 3.32 & 0.93 & 1.77 & 0.39 & 1.34 & 1.20 & 1.91 & 1.55 & 2.59 & 3.29 & 2.92 & 0.97 & 7.76 & 4.32 & 0.60 \\
\hline $\mathrm{CaO}$ & 5.07 & 9.62 & 3.83 & 1.84 & 9.45 & 6.76 & 2.33 & 4.30 & 1.14 & 4.08 & 5.50 & 4.31 & 4.90 & 2.19 & 7.17 & 4.66 & 47.76 & 40.81 & 43.86 & 18.83 \\
\hline $\mathrm{Na}_{2} \mathrm{O}$ & 0.49 & 2.40 & 3.75 & 3.67 & 2.90 & 3.47 & 5.46 & 3.78 & 3.54 & 2.03 & 0.45 & 0.58 & 0.51 & 1.60 & 0.80 & 1.19 & 0.08 & & 0.08 & 22.17 \\
\hline $\mathrm{K}_{2} \mathrm{O}$ & 0.34 & 0.39 & 2.73 & 4.06 & 1.10 & 1.61 & 4.97 & 2.16 & 4.29 & 2.08 & 1.30 & 2.11 & 1.70 & 3.59 & 3.49 & 3.52 & 0.57 & & 0.57 & 0.32 \\
\hline $\mathrm{P}_{2} \mathrm{O}_{5}$ & 0.10 & 0.93 & 0.18 & 0.12 & 0.35 & 0.21 & 0.21 & 0.15 & 0.07 & 0.08 & 0.08 & 0.10 & 0.09 & 0.16 & 0.10 & 0.13 & 0.16 & 0.07 & 0.11 & \\
\hline $\mathrm{CO}_{2}$ & 0.30 & 0.24 & 0.08 & 0.05 & 0.11 & 0.05 & 0.09 & 0.06 & 0.08 & 2.49 & 5.00 & 3.91 & 4.45 & 1.30 & 6.07 & 3.67 & 38.43 & 35.77 & 36.74 & 1.14 \\
\hline$s$ & 0.02 & 0.02 & 0.02 & 0.02 & 0.07 & 0.36 & 0.07 & 0.19 & 0.06 & 0.01 & & & 0.02 & 0.24 & & 0.24 & 0.11 & & 0.11 & \\
\hline $\mathrm{SO}_{3}$ & 0.02 & 0.02 & 0.02 & 0.01 & 0.09 & 0.04 & 0.08 & 0.28 & 0.01 & 0.00 & 0.07 & 0.70 & 0.38 & & 0.60 & 0.59 & 0.02 & 3.12 & 1.55 & 24.48 \\
\hline $\mathrm{H}_{2} \mathrm{O}+$ & 4.24 & 0.86 & 1.04 & 0.77 & 1.38 & 1.17 & 1.62 & 1.19 & 1.41 & 2.87 & 1.30 & 3.01 & 2.15 & 4.99 & 4.98 & 4.96 & 0.84 & & 0.84 & 5.38 \\
\hline c & 0.02 & 0.02 & 0.02 & 0.03 & 0.01 & 0.02 & 0.02 & 0.02 & 0.02 & 1.53 & & 0.26 & 0.26 & 0.60 & 0.67 & 0.63 & & 0.23 & 0.23 & \\
\hline $\mathrm{Cl}$ & 0.07 & 0. & 0.07 & 0. & 0.07 & 0.05 & 0.16 & 0.12 & 0.11 & 0.01 & & & 0.06 & & & 0.08 & & & 0.04 & 25.97 \\
\hline Sum & 100.00 & 100.00 & 100.00 & 100.00 & 100.00 & 100.00 & 100.00 & 100.00 & 100.00 & 100.000 & 100.00 & 100.00 & 100.00 & 100.00 & 100.00 & 100.00 & 100.00 & 100.00 & 100.00 & 100.00 \\
\hline
\end{tabular}

Note, organic/reduced $\mathrm{C}$ has not often been analysed with exception of shales (c.f. the work of Ronov, in Meybeck 1982). C and Cl content for some rock classes have been assumed to be the same as the average of basalt and granite or similar to basalt (grey colour background)

Step 2: determination of average rock-class composition per lithological classes

Proportions of rock-classes commonly used in geochemical studies are translated into proportions on lithological classes used in the global lithological map of Dürr et al. (2005) and are based on reviews of additional sources and knowledge based on regional literature. The rock classification translation into applied lithological classes is based on the following assumptions:

- Basic-Ultrabasic Plutonics (PB): 1/2 Peridotite (composition similar to Lherzolite) $+1 / 2$ Gabbro (Dürr 2003; Rudnick and Gao 2003)

- Acid Plutonics (PA): 2/3 Granodiorite + 1/3 Granite (Berner and Berner 1995)

- Acid Volcanics Rocks (VA): Rhyolite (main occurrences) (note: a substantial part of VA may be of dacitic composition)

- Basic and Intermediate Volcanic Rocks (VB): 3/4 Basalt $+1 / 4$ Andesite (Berner and Berner 1995; Dürr 2003; Dürr et al. 2005)

- Precambrian Basement (PR), Metamorphic Rocks (MT): $60 \%$ Granodiorite $+30 \%$ Granite $+10 \%$ Basalt (for basement rocks only, not considering sediments) (Dürr 2003)

- Complex Lithology (CL: folded sedimentary rocks mixed with volcanic rocks in mountain regions): $90 \%$ sedimentary rocks $+8 \%$ volcanics $+2 \%$ ultrabasics (Dürr 2003; Dürr et al. 2005), with:

- Sedimentary rocks: $15 \%$ carbonates $+60 \%$ shales $+25 \%$ sandstones

- Volcanics: $85 \%$ basalt $+15 \%$ trachyte

- Ultrabasics: Peridotite
- Siliciclastic Sedimentary Rocks (SS): $70 \%$ shale + 30\% sandstones (Berner and Berner 1995; Dürr 2003; Dürr et al. 2005)

- Carbonate Sedimentary Rocks (SC): pure carbonate sedimentary rocks (Wedepohl 1969)

- Evaporites (EP): $25 \%$ shales $+25 \%$ carbonates sediments + average salt composition (Li 2000)

- Dune Sands (DS): as sandstones (Berner and Berner 1995)

- Loess (LO): as Chinese loess (Taylor et al. 1983; Taylor and Mclennan 1985)

- Semi- to Unconsolidated Sediments (SU), Mixed Sedimentary Rocks (SM), Alluvial Deposits (AD): $15 \%$ carbonates $+60 \%$ shales $+25 \%$ sandstones (Berner and Berner 1995; Dürr 2003; Dürr et al. 2005)

Step 3: calculation of the geochemical composition of each lithological class

In a third step, the geochemical compositions of lithological classes are calculated based on the proportions of rock types identified in step 2 (Table 3 ). In addition, the average geochemical composition of the continents and basins draining to major oceans are calculated (Table 4).

Step 4: comparison with the geochemical composition of the crust

The average geochemical composition of the terrestrial surface is calculated as the area-weighted average of the geochemical composition of the applied lithological classes. Data of the terrestrial surface are compared with geochemical models of the continental crust (Taylor and Mclennan 1995; Wedepohl 1995; Rudnick and Gao 2003). 


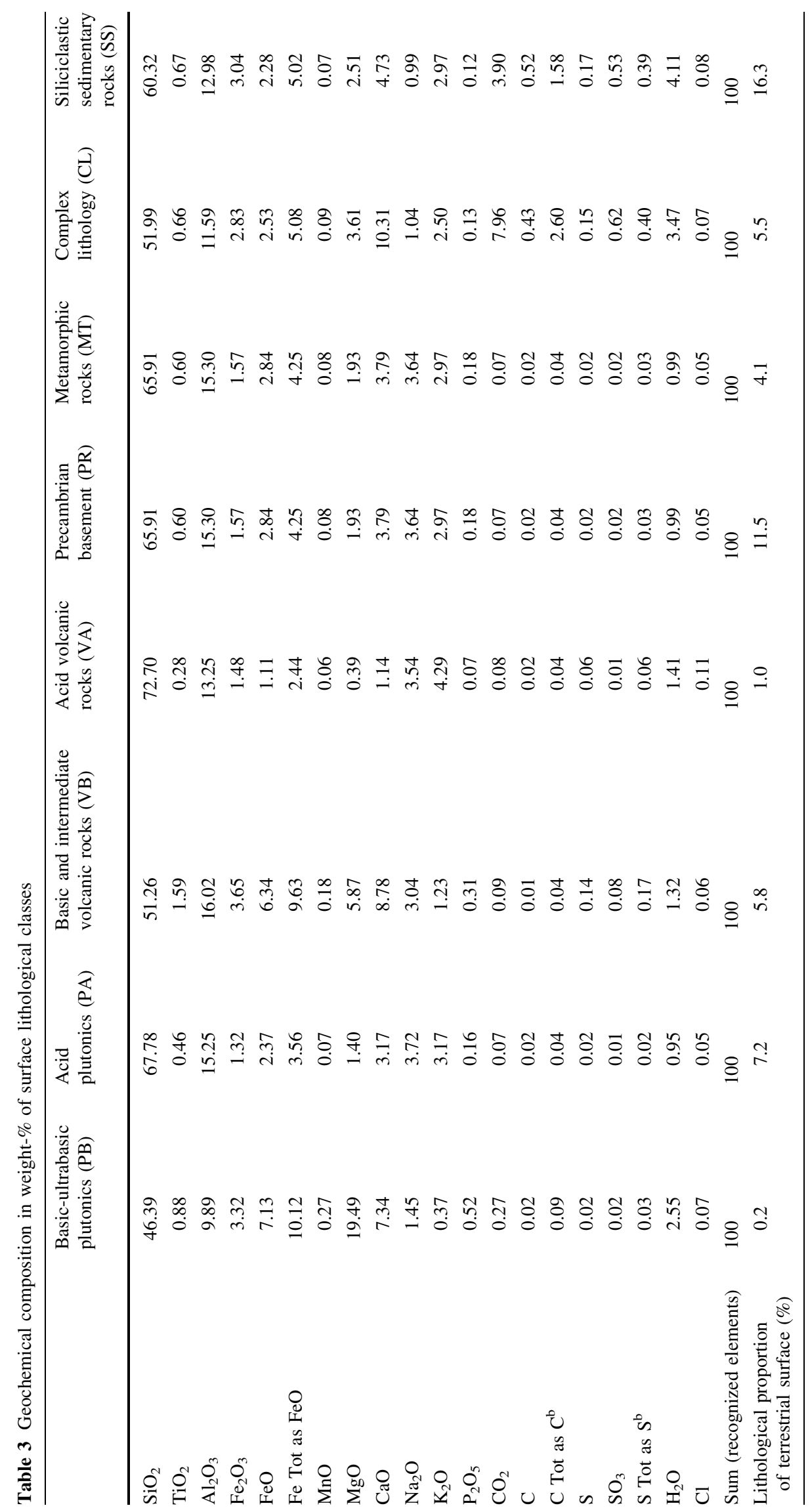




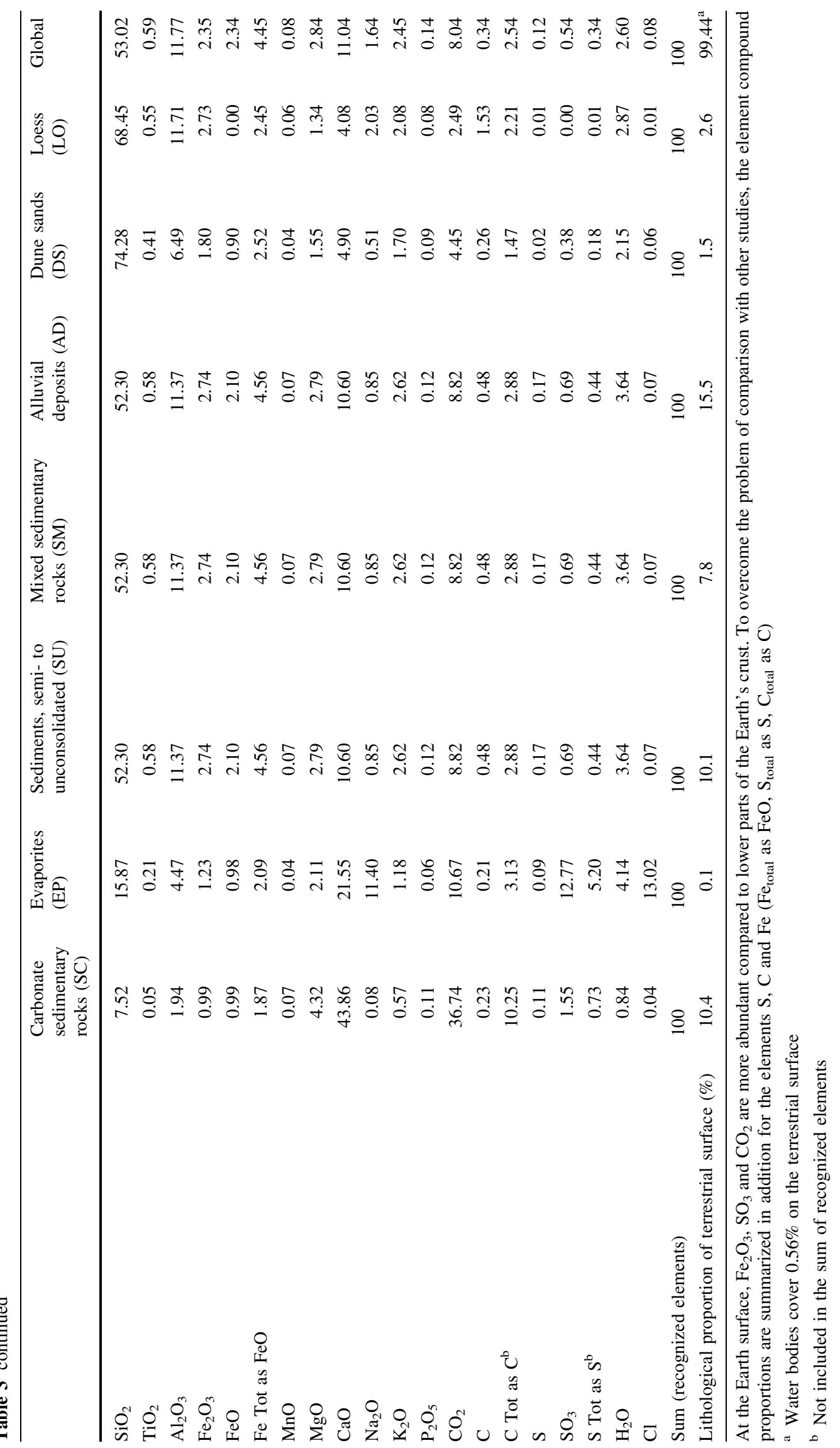


Table 4 Average geochemical composition of the continents and of the catchment areas of major oceans and the Mediterranean Sea

\begin{tabular}{|c|c|c|c|c|c|c|c|c|c|c|c|c|c|}
\hline & $\begin{array}{l}\text { North } \\
\text { America }\end{array}$ & $\begin{array}{l}\text { South } \\
\text { America }\end{array}$ & Australasia & Africa & Asia & Europe & $\begin{array}{l}\text { Arctic } \\
\text { Ocean }\end{array}$ & $\begin{array}{l}\text { Atlantic } \\
\text { Ocean }\end{array}$ & $\begin{array}{l}\text { Indian } \\
\text { Ocean }\end{array}$ & $\begin{array}{l}\text { Pacific } \\
\text { Ocean }\end{array}$ & Mediterranean & Endorheic & Global \\
\hline $\mathrm{SiO}_{2}$ & 50.80 & $\mathbf{5 7 . 3 8}$ & 53.96 & 53.95 & 52.49 & 48.75 & 51.91 & 54.83 & 52.32 & 53.70 & 48.24 & 52.51 & 53.03 \\
\hline $\mathrm{TiO}_{2}$ & 0.60 & 0.65 & 0.58 & 0.57 & 0.59 & 0.51 & 0.58 & 0.57 & 0.59 & 0.68 & 0.52 & 0.58 & 0.59 \\
\hline $\mathrm{Al}_{2} \mathrm{O}_{3}$ & 11.65 & 12.82 & 12.11 & 11.81 & 11.58 & 10.53 & 11.61 & 12.10 & 11.90 & 12.36 & 10.22 & 11.23 & 11.77 \\
\hline $\mathrm{Fe}_{2} \mathrm{O}_{3}$ & 2.25 & 2.48 & 2.37 & 2.23 & 2.43 & 2.31 & 2.36 & 2.28 & 2.27 & 2.51 & 2.24 & 2.49 & 2.35 \\
\hline $\mathrm{FeO}$ & 2.46 & 2.45 & 2.36 & 2.33 & 2.34 & 1.94 & 2.31 & 2.27 & 2.47 & 2.70 & 2.02 & 2.21 & 2.34 \\
\hline $\mathrm{MnO}$ & 0.09 & 0.08 & 0.08 & 0.08 & 0.08 & 0.08 & 0.08 & 0.08 & 0.08 & 0.09 & 0.08 & 0.08 & 0.08 \\
\hline $\mathrm{MgO}$ & 2.99 & 2.64 & 2.74 & 2.70 & 2.94 & 2.96 & 2.90 & 2.63 & 2.90 & 3.10 & 2.99 & 2.89 & 2.84 \\
\hline $\mathrm{CaO}$ & 12.61 & 7.91 & 10.14 & 10.74 & 11.23 & 14.12 & 11.63 & 10.04 & 11.46 & 10.15 & 14.84 & 11.20 & 11.04 \\
\hline $\mathrm{Na}_{2} \mathrm{O}$ & 1.77 & 1.86 & 1.67 & 1.73 & 1.51 & 1.27 & 1.53 & 1.78 & 1.78 & 1.79 & 1.31 & 1.33 & 1.64 \\
\hline $\mathrm{K}_{2} \mathrm{O}$ & 2.32 & 2.64 & 2.59 & 2.48 & 2.44 & 2.27 & 2.46 & 2.55 & 2.44 & 2.43 & 2.14 & 2.43 & 2.45 \\
\hline $\mathrm{P}_{2} \mathrm{O}_{5}$ & 0.15 & 0.14 & 0.14 & 0.14 & 0.14 & 0.13 & 0.14 & 0.14 & 0.15 & 0.15 & 0.13 & 0.13 & 0.14 \\
\hline $\mathrm{CO}_{2}$ & 9.01 & 5.23 & 7.41 & 7.77 & 8.32 & 11.14 & 8.69 & 7.20 & 8.18 & 6.79 & 11.52 & 8.59 & 8.04 \\
\hline $\mathrm{S}$ & 0.11 & 0.12 & 0.12 & 0.11 & 0.13 & 0.12 & 0.12 & 0.11 & 0.11 & 0.12 & 0.11 & 0.13 & 0.12 \\
\hline $\mathrm{SO}_{3}$ & 0.53 & 0.42 & 0.57 & 0.52 & 0.58 & 0.65 & 0.57 & 0.48 & 0.55 & 0.47 & 0.67 & 0.68 & 0.54 \\
\hline $\mathrm{H}_{2} \mathrm{O}$ & 2.30 & 2.73 & 2.74 & 2.46 & 2.75 & 2.71 & 2.69 & 2.53 & 2.43 & 2.57 & 2.49 & 2.98 & 2.60 \\
\hline $\mathrm{C}$ & 0.31 & 0.37 & 0.33 & 0.29 & 0.36 & 0.45 & 0.35 & 0.34 & 0.29 & 0.32 & 0.40 & 0.40 & 0.34 \\
\hline $\mathrm{Cl}$ & 0.06 & 0.07 & 0.11 & 0.08 & 0.09 & 0.06 & 0.06 & 0.06 & 0.09 & 0.07 & 0.07 & 0.16 & 0.08 \\
\hline Sum & 100 & 100 & 100 & 100 & 100 & 100 & 100 & 100 & 100 & 100 & 100 & 100 & 100 \\
\hline
\end{tabular}

Bold numbers mark either maximum values or minimum values, or values close to the maximum/minimum

Two approaches are typically applied to estimate the composition of the continental crust. These are in brief:

(a) weighted averages of the compositions of shield/basement rocks, exposed at the Earth's surface, are used as representative for the Earth's crust (or compartments);

(b) assumptions of the rock composition of distinguished compartments of the continental crust are scaled with depth, while considering changes in rock types and their composition (e.g. Wedepohl 1995).

Details of the different approaches are described in Rudnick and Gao (2003). Because the geochemical model of Rudnick and Gao (2003) is the most recent one and includes more analysis than the other two models, it is here assumed to be the more representative one. Uncertainty analysis is provided by assuming an error of $10 \%$ for each element for derived averages of the terrestrial surface and averages of the upper continental crust (last two columns in Table 1). This simple assumption is based on typical errors of measurements and spatial errors due to the mapping procedure (Rudnick and Gao 2003; Moosdorf et al. 2010).

\section{Results}

The elements $\mathrm{Ca}, \mathrm{S}, \mathrm{C}$ and $\mathrm{Cl}$ (and to a lesser extent $\mathrm{Mg}$ ) are notably enriched on the terrestrial surface if compared to the average upper crust (Table 1). $\mathrm{Ca}$ (and $\mathrm{Mg}$ ) enrichment can be attributed to the abundance of carbonates at the terrestrial surface, which are more soluble than silicates. Significant amounts of $\mathrm{Mg}$ are also present in basic plutonics and volcanics (Table 3), which, however, are less abundant than carbonate sedimentary rocks (SC) (Table 3). The increased $\mathrm{Cl}$ proportion at the terrestrial surface is attributed to the $\mathrm{Cl}$ content in evaporites (EP), whereas the high $\mathrm{S}$ proportion at the terrestrial surface can be attributed to both evaporites (EP) as well as carbonate and further sediment lithological classes. Both $\mathrm{Cl}$ and $\mathrm{S}$ contents are generally low and often not accurately known. Results for $\mathrm{S}$ depend in addition on the assumed composition of sedimentary classes (c.f. Table 2).

The terrestrial surface is relatively depleted in $\mathrm{Na}$ and to a smaller extent in $\mathrm{Al}, \mathrm{Si}$ and $\mathrm{K}$ (Table 1), compared to the average upper crust, which is in part due to the abundance of carbonates. $\mathrm{Na}$ is depleted even if compared to the composition of the lower crust. $\mathrm{K}$ concentration at the terrestrial surface shows no large difference compared to the upper crust in the most recent model of the geochemistry of upper continental crust (Rudnick and Gao 2003), but is significantly increased compared to the lower crust (Table 1). However, while considering carbonate abundance, increased levels of $\mathrm{K}$ can be observed for some crystalline as well as some sedimentary classes (e.g. siliciclastic sedimentary rocks, alluvial deposits and other unconsolidated sediments). Thus, non-carbonate terrestrial surface rocks are slightly enriched in $\mathrm{K}$ if compared to the 
upper crust, and $\mathrm{K}$ is enriched at the terrestrial surface compared to the total crust.

The main observations of relative enrichment or depletion of certain elements (i.e. $\mathrm{Ca}, \mathrm{Na}, \mathrm{S}, \mathrm{C}, \mathrm{Cl}$ ) on the terrestrial surface compared to the upper continental crust are insensitive to a $10 \%$ change of the assumed elementary composition of the individual lithological units (Table 1).

The contents of the elements $\mathrm{P}, \mathrm{Fe}, \mathrm{Mn}$ and $\mathrm{Ti}$ at the terrestrial surface are not significantly different from the upper crust considering the variability between the three geochemical compositions of the upper crust used (Table 1). However, they show some significant differences towards the lower crust. Mn varies little among lithological classes in general, with the exception of higher contents in basic igneous lithologies. No large difference to the upper crust can be observed for Fe, due to its large contents in sediments or basic igneous lithologies VB and PB that compensate for carbonate abundance at the surface. Dissolved $\mathrm{Fe}$ is in general immobilized under typical surface conditions because it precipitates preferentially as oxide or hydroxide in sediments. Fe-content differences to the middle and lower crust are in accordance with the gradient identified by Rudnick and Gao (2003).

$\mathrm{P}$ as an important nutrient for ecosystems shows some variation in the presented compilation of data. However, contents are low.

Comparing the geochemical composition of the continents (Table 4), the largest observed differences (between Europe and South America) is caused by the different carbonate abundances on those continents (19\% vs. $1.9 \%$; cf. Dürr et al. 2005). In a similar way, the difference in carbonate abundance, but also volcanic abundance, influence the differences observed in the geochemical composition of basins draining to the Pacific and Mediterranean Sea. Maps of the global distribution of elements discussed are provided in the supplementary information.

\section{Discussion}

The differences observed between terrestrial surface and continental crust are largely influenced by a few key processes which are discussed briefly below: chemical weathering, aggregation of residuals of chemical weathering on the terrestrial surface in sediments, relocation of marine sediments to the terrestrial surface (partly altered silicate-dominated sediments and carbonate products from biomineralization), evaporite deposits, as well as redox processes in sediments (compare levels of reduced $S$ in shales in Table 2).

Chemical weathering processes lead to a preferential depletion of some elements in rocks. For example, certain differences of major cation loss rates (into natural waters) were reported for igneous rocks (Goldich 1938; Blum 1994; Van der Weijden and Pacheco 2003) but also sediments (Meybeck 1987; Hartmann and Moosdorf 2010). Chemical weathering produces dissolved products and can leave, in case of incongruent chemical weathering, particulate residues (secondary minerals). The former are nearly entirely transported to the oceans (with the exception of dissolved silica: Beusen et al. 2009; Hartmann et al. 2010 b), while some proportion of the latter is stored in the fluvial system leaving only a certain extent for export to the oceans via physical erosion.

Sediment particles of terrestrial origin influence the geochemical composition of marine sediments, which are partly relocated to the terrestrial system via tectonic processes. A second pathway is the transfer of marine sediments via subduction processes into crystalline rocks of the continental crust. There, the signature of terrestrial material can be identified in crystalline rocks (Reymer and Schubert 1984; White et al. 1985; Morris and Tera 1989; Hofmann 2007). Thus, mass transfer of terrestrial material, altered by preferential depletion of elements and subsequent development of secondary minerals, to the ocean via chemical and physical weathering indirectly influences the evolution of the continental crust.

Sediments are assumed to amount to 14 weight $\%$ of the upper continental crust (considering a depth of $20 \mathrm{~km}$ ), $14.6 \%$ of those are carbonates (e.g. Wedepohl 1995). Results suggest that terrestrial surface processes and thus geochemical composition of sediments are important for the geochemical evolution of the continental crust, at least for the surface geochemistry, as sediments cover $\sim 2 / 3$ of the landmass (c.f. Table 3 and Dürr et al. 2005). For example, carbonate rock weathering rates are thought to be a magnitude larger than those of granites (Meybeck 1987) and it should be kept in mind that some sedimentary lithological classes (SS and SM) are characterised by notable amounts of carbonates (c.f. Dürr et al. 2005 with Moosdorf et al. 2010), contributing to an increased Ca-flux from these lithological classes (Hartmann and Moosdorf 2010).

The selective element depletion of the terrestrial surface is, in addition to chemical weathering, regulated by physical erosion because erosion rates are different between lithological classes (c.f. Meybeck 1987; Millot et al. 2002).

Thus, processes determining sediment composition and element transport to the ocean have a pronounced effect on the geochemical evolution of the Earth's continental surface layers, and, in addition, influence the geochemical evolution of continents because oceanic sediments partly contain material of terrestrial origin (Hofmann and White 1982; Plank and Langmuir 1998; Plank 2005). For example, marine sediment transferred to the continental crust produces crystalline rocks that are deficient in $\mathrm{Na}$ and probably $\mathrm{Ca}$, relative to primary igneous rocks. Locally, the 
Ca deficiency depends on the proportion of carbonates in sediments (Plank and Langmuir 1998; Plank 2005). Substantial differences in weathering rate capacity for certain elements may thus impact the fractionation of the continental crust due to preferential recycling of elements back to the continental crust via the oceanic crust. It is uncertain, however, how large the weathering-derived component in the continental crust is (Rudnick 1995). Note that based on the data in Table 2, the lithological class combination $\mathrm{PB}+\mathrm{PA}+\mathrm{VB}+\mathrm{VA}+\mathrm{PB}+\mathrm{MT}$ is enriched in $\mathrm{Ca}$ by $\sim 28 \%$ if compared to the upper continental crust (after Rudnick and Gao 2003).

Part of the observed compositional differences between terrestrial surfaces and continental crust is due to the uplift of a significant proportion of carbonate-rich marine sediments that are not incorporated into the continental igneous rocks via subduction. This explains the high $\mathrm{Ca}$ and (partly) $\mathrm{Mg}$ abundance on the terrestrial surface compared to the upper continental crust. This suggests that erosion was not capable to compensate the enrichment of carbonate sedimentary rocks at the terrestrial surface caused by tectonic processes.

Mass balance calculations (Lee et al. 2008) suggest that $\mathrm{Mg}$ is preferentially lost from continental rocks via chemical weathering at the terrestrial surface, and transported to the ocean. A significant proportion of oceanic dissolved $\mathrm{Mg}$ is fixed in the oceanic crust by cation exchange (predominantly with $\mathrm{Ca}$ ) at mid-ocean ridges or submarine basalts in general (Albarede and Michard 1986; Albarede 1998; Talbi and Honnorez 2003; Paul et al. 2006). From there it is removed via subduction of the altered oceanic crust to the mantle (Lee et al. 2008).

However, the major process that explains most of the $\mathrm{Mg}$ difference observed here, between the terrestrial surface and upper continental crust (enrichment), is the transport of marine $\mathrm{Mg}$ to the terrestrial continental crust as carbonate rocks, via (plate) tectonic processes. Carbonates are the major reservoirs for lithogenic $\mathrm{C}$, underscoring the role of sediment abundance for the $\mathrm{C}$ fractionation between crustal compartments compared (Kempe 1979). The question since when the terrestrial Earth surface is enriched with $\mathrm{Ca}$ and probably $\mathrm{Mg}$ due to the movement of significant amounts of carbonates to the terrestrial surface should be addressed in the future. A substantial change in the abundance of carbonates on the terrestrial surface may significantly influence the atmospheric $\mathrm{CO}_{2}$ uptake due to chemical weathering because of the relatively high weathering rates if compared to other lithological classes (Hartmann et al. 2009). If such a change in carbonate abundance at the terrestrial surface happens in a relatively short (geological) time period and the increase in chemical weathering rates are substantially larger than rate increases of carbonate precipitation in the ocean for a certain period, it may affect the climate system. For discussion of further relevant processes compare Arvidson et al. (2006) and references therein.

The terrestrial $\mathrm{Na}$ depletion is due to its low concentrations in sediments, suggesting an aggregation in other compartments of the Earth. It should be kept in mind that $\mathrm{Na}^{+}$has a long oceanic residence time. It is removed from the oceans predominantly by precipitation of halite, and probably to a lesser part by pore water subduction and by reverse weathering (e.g. Mackenzie and Garrels 1966; Michalopoulos and Aller 1995; Michalopoulos and Aller 2004; Arvidson et al. 2006; Hay et al. 2006). Field evidence suggests that substantial evaporite precipitation episodically occurs in Earth history, every time depositing large volumes of salts (Hay et al. 2006). However, theoretical models on the geochemical development of the ocean suggest a more continuous evaporite extraction (Arvidson et al. 2006). Nevertheless, the evaporite volume is small, $\sim 5 \%$ of total sediments (Garrels and Mackenzie 1971), and evaporites are thus unlikely to influence the sedimentary Na budget significantly (Goldschmidt 1958, in Rudnick 1995). They do influence the $\mathrm{Cl}$ abundance at the terrestrial surface, however, due to the very low Cl-concentrations in all other lithological classes if compared to evaporites (Table 2, lithological class EP).

The enrichment of $\mathrm{S}$ at the terrestrial surface is predominantly due to oxidized $\mathrm{S}\left(\mathrm{S}_{\mathrm{SO} 3}\right)$ and less due to reduced $\mathrm{S}_{\mathrm{S}}$ in sediments (ratio $\mathrm{S}_{\mathrm{SO} 3} / \mathrm{S}_{\mathrm{S}} \sim 1.8$ ) (Table 3). This suggests that evaporite deposition may be more important for the accumulation of $S$ at the terrestrial surface than reduced sulphur in marine sediments which have been moved to the terrestrial surface. The abundance of sulphate in rocks at the terrestrial surface depends on the co-occurrence of wet/dry climate conditions and rocks bearing high sulphate concentrations. Because of this, the $\mathrm{S}_{\mathrm{SO} 3} / \mathrm{S}_{\mathrm{S}}$-ratio found for the terrestrial surface today may have been different for other periods of Earth history (compare for the spatial correlations between applied lithological classes and annual runoff in Hartmann et al. 2009).

The maps presented (supplement information) provide an overview of the regional distribution of elements at the terrestrial surface (below soils). They will certainly be improved in the future, when detailed information on tectonic settings and regional rock geochemistry is incorporated. However, strong contrasts in the spatial abundance of the geochemical properties distinguished can be observed in the figures presented due to the different properties of the lithological units. The maps developed here, and future, refined maps, are valuable for predicting land-ocean matter fluxes in a spatially explicit manner (Hartmann and Moosdorf 2010). 


\section{Conclusions}

Enrichment and depletion of elements (specifically of Ca, $\mathrm{Mg}, \mathrm{Na}, \mathrm{C}, \mathrm{S}$ and $\mathrm{Cl}$ ) in the terrestrial surface can be explained by either preferential depletion in sediments (like $\mathrm{Na}$ ), the aggregation of sulphide in marine sediments (sulphate reduction), plate tectonics causing a segregation of material over geological time scales, and the abundance of carbonates and evaporites on the terrestrial surface. The significant differences observed between the terrestrial surface and continental crust as a whole illustrate the role of biotic and abiotic Earth surface processes (e.g. carbonate precipitation in the ocean and chemical weathering) for the geochemical layering of the continental crust.

The average values presented here allow insights into the role of the terrestrial surface in global material cycles, especially with respect to surface waters being the main agent for transport of solid and dissolved matter to the oceans.

A significant improvement of this first estimate can be achieved if local or regional geochemical compositions per lithological class are combined with global or better regional lithological maps of an improved resolution. This can be achieved because future lithological classification schemes may include differences in origin of sediments (terrestrial vs. marine) and diagenetic history. A spatial representation of the geochemical (or mineralogical) composition of the terrestrial surface can also contribute additional information for Earth system models focusing on the climate system, e.g. to better distinguish $\mathrm{CO}_{2}$-consumption by silicate and carbonate chemical weathering or to estimate the phosphorus-release by chemical weathering to soils and ecosystems (Berner 2006; Hartmann et al. 2009; Hartmann 2009; Godderis et al. 2009; Hartmann and Moosdorf 2010; Roelandt et al. 2010).

Acknowledgments The work of Jens Hartmann and Nils Moosdorf has been supported through the German Science Foundation (DFGproject HA 4472/6-1 and the Cluster of Excellence 'CliSAP' (EXC177), Universität Hamburg). H.H. Dürr was funded by Utrecht University (High Potential Project G-NUX) and the EU FP6 project CARBO-North (project number 036993). The comments of two reviewers helped to improve a previous version of the manuscript.

Open Access This article is distributed under the terms of the Creative Commons Attribution Noncommercial License which permits any noncommercial use, distribution, and reproduction in any medium, provided the original author(s) and source are credited.

\section{References}

Albarede F (1998) The growth of continental crust. Tectonophysics 296(1-2):1-14
Albarede F, Michard A (1986) Transfer of continental Mg, S, O and U to the mantle through hydrothermal alteration of the oceaniccrust. Chem Geol 57(1-2):1-15

Amiotte-Suchet P, Probst JL, Ludwig W (2003) Worldwide distribution of continental rock lithology: implications for the atmospheric/soil $\mathrm{CO}_{2}$ uptake by continental weathering and alkalinity river transport to the oceans. Glob Biogeochem Cycle 17(2):GB1038

Arvidson RS, Mackenzie FT, Guidry M (2006) MAGic: a phanerozoic model for the geochemical cycling of major rock-forming components. Am J Sci 306(3):135-190

Berner RA (2006) GEOCARBSULF: a combined model for phanerozoic atmospheric $\mathrm{O}_{2}$ and $\mathrm{CO}_{2}$. Geochim Cosmochim Acta 70(23):5653-5664

Berner EK, Berner RA (1995) Global environment: water, air, and geochemical cycles. Prentice Hall, Upper Saddle River

Beusen AHW, Bouwman AF, Durr HH, Dekkers ALM, Hartmann J (2009) Global patterns of dissolved silica export to the coastal zone: results from a spatially explicit global model. Glob Biogeochem Cycle 23, pp 1-13. doi:10.1029/2008GB003281

Blum AE (1994) Feldspars in weatheirng. In: Nato advanced science institutes series, series $\mathrm{C}$, mathematical and physical sciences. pp 595-630

Bluth GJS, Kump LR (1994) Lithologic and climatologic controls of river chemistry. Geochim Cosmochim Acta 58(10):2341-2359

Condie KC (1993) Chemical-composition and evolution of the upper continental-crust-contrasting results from surface samples and shales. Chem Geol 104(1-4):1-37

Dessert C, Dupre B, Gaillardet J, Francois LM, Allegre CJ (2003) Basalt weathering laws and the impact of basalt weathering on the global carbon cycle. Chem Geol 202:257-273

Donnadieu Y, Godderis Y, Pierrehumbert R, Dromart G, Fluteau F, Jacob R (2006) A GEOCLIM simulation of climatic and biogeochemical consequences of Pangea breakup. Geochem Geophys Geosyst 7(11):1-21

Dürr HH (2003) Vers une typologie des systémes fluviaux à l'échelle globale: quelques concepts et exemples à résolution moyenne. Académie De Paris, Université Pierre et Marie Curie, Paris

Dürr HH, Meybeck M, Dürr SH (2005) Lithologic composition of the Earth's continental surfaces derived from a new digital map emphasizing riverine material transfer. Glob Biogeochem Cycle 19(4):GB4S10

Edmond JM, Measures C, Mcduff RE, Chan LH, Collier R, Grant B, Gordon LI, Corliss JB (1979) Ridge crest hydrothermal activity and the balances of the major and minor elements in the oceanGalapagos data. Earth Planet Sci Lett 46(1):1-18

Gaillardet J, Dupre B, Allegre CJ (1999a) Geochemistry of large river suspended sediments: silicate weathering or recycling tracer? Geochim Cosmochim Acta 63(23-24):4037-4051

Gaillardet J, Dupre B, Louvat P, Allegre CJ (1999b) Global silicate weathering and $\mathrm{CO}_{2}$ consumption rates deduced from the chemistry of large rivers. Chem Geol 159(1-4):3-30

Garrels RM, Mackenzie FT (1967) Origin of chemical compositions of some springs and lakes. Adv Chem Ser 67:222-242

Garrels RM, Mackenzie FT (1971) The evolution of sedimentary rocks. Norton, New York

Godderis Y, Roelandt C, Schott J, Pierret MC, Francois LM (2009) Towards an integrated model of weathering, climate, and biospheric processes. Thermodyn Kinet Water Rock Interact 70:411-434

Goldich SS (1938) A study in rock-weathering. J Geol 46(1):17-58

Hartmann J (2009) Bicarbonate-fluxes and $\mathrm{CO}_{2}$-consumption by chemical weathering on the Japanese archipelago-application of a multi-lithological model framework. Chem Geol 65(3/4): 237-271. doi:10.1016/j.chemgeo.2009.03.024

Hartmann J, Moosdorf N (2010) Chemical weathering rates of silicate-dominated lithological classes and associated liberation 
rates of phosphorus on the Japanese Archipelago-implications for global scale analysis. Chem Geol, pp 1-32. doi:10.1016/ j.chemgeo.2010.12.004

Hartmann J, Jansen N, Dürr HH, Kempe S, Köhler P (2009) Global $\mathrm{CO}_{2}$-consumption by chemical weathering: what is the contribution of highly active weathering regions? Glob Planet Chang 69:185-194. doi:10.1016/j.gloplacha.2009.07.007

Hartmann J, Jansen N, Dürr HH, Harashima A, Okubo K, Kempe S (2010a) Predicting riverine dissolved silica fluxes to coastal zones from a hyperactive region and analysis of their first-order controls. Int J Earth Sci 99(1):207-230. doi:10.1007/s00531008-0381-5

Hartmann J, Levy JK, Kempe S (2010b) Increasing dissolved silica trends in the Rhine River: an effect of recovery from high $\mathrm{P}$ loads? Limnology, pp 1-11. doi:10.1007/s10201-010-0322-4

Hawkesworth CJ, Kemp AIS (2006) Evolution of the continental crust. Nature 443(7113):811-817

Hay WW, Migdisov A, Balukhovsky AN, Wold CN, Flogel S, Soding E (2006) Evaporites and the salinity of the ocean during the phanerozoic: implications for climate, ocean circulation and life. Palaeogeogr Palaeoclimatol Palaeoecol 240(1-2):3-46

Hofmann AW (2007) Geochemistry-the lost continents. Nature 448(7154):655-656

Hofmann AW, White WM (1982) Mantle plumes from ancient oceanic-crust. Earth Planet Sci Lett 57(2):421-436

Imai N, Terashima S, Ohta A, Mikoshiba M, Okai T, Tachibana Y, Togashi S, Matsuhisa Y, Kanai Y, Kamioka H (2004) Geochemical map of Japan. Geological Survey of Japan, AIST

Imrie CE, Korre A, Munoz-Melendez G, Thornton I, Durucan S (2008) Application of factorial kriging analysis to the FOREGS European topsoil geochemistry database. Sci Total Environ 393(1):96-110

Kempe S (1979) Carbon in the rock cycle. In: Bolin B, Degens ET, Kempe S, Ketner P (eds) The global carbon cycle-scope 13. Scientific Committee on Problems on the Environment (SCOPE), Old Woking, pp 343-375

Le Maitre RW (1976) The chemical variability of some common igneous rocks. J Petrol 17(4):589-598

Lee CTA, Morton DM, Little MG, Kistler R, Horodyskyj UN, Leeman WP, Agranier A (2008) Regulating continent growth and composition by chemical weathering. Proc Natl Acad Sci USA 105(13):4981-4986

Lerman A, Wu LL, Mackenzie FT (2007) $\mathrm{CO}_{2}$ and $\mathrm{H} 2 \mathrm{SO} 4$ consumption in weathering and material transport to the ocean, and their role in the global carbon balance. Mar Chem 106(1-2): $326-350$

Li YH (2000) A compendium of geochemistry: from solar nebula to the human brain. Princeton University Press, Princeton

Mackenzie FT, Garrels RM (1966) Chemical mass balance between rivers and oceans. Am J Sci 264(7):507-525

Max Planck Institute for Chemistry, Mainz (2006) Geochemistry of rocks of the oceans and continents, GEOROC. http://georoc. mpch-mainz.gwdg.de/georoc/. Access date: 5-27-2006

Meybeck M (1982) Carbon, nitrogen, and phosphorus transport by world rivers. Am J Sci 282(4):401-450

Meybeck M (1987) Global chemical-weathering of surficial rocks estimated from river dissolved loads. Am J Sci 287(5):401-428

Meybeck M (2003) Global occurence of major elements in rivers. In: Drever JI (ed) Surface and ground water, weathering and soils. Elsevier, Amsterdam, pp 207-223

Michalopoulos P, Aller RC (1995) Rapid clay mineral formation in Amazon delta sediments-reverse weathering and oceanic elemental cycles. Science 270(5236):614-617

Michalopoulos P, Aller RC (2004) Early diagenesis of biogenic silica in the Amazon delta: alteration, authigenic clay formation, and storage. Geochim Cosmochim Acta 68(5):1061-1085
Millot R, Gaillardet J, Dupre B, Allegre CJ (2002) The global control of silicate weathering rates and the coupling with physical erosion: new insights from rivers of the Canadian Shield. Earth Planet Sci Lett 196(1-2):83-98

Moosdorf N, Hartmann J, Dürr HH (2010) Lithological composition of the North American continent and implications of lithological map resolution for dissolved silica flux modeling. Geochem Geophys Geosyst 11(11):1-18. doi:10.1029/2010GC003259

Morris J, Tera F (1989) Be-10 and Be-9 in mineral separates and whole rocks from volcanic arcs-implications for sediment subduction. Geochim Cosmochim Acta 53(12):3197-3206

Oliva P, Viers J, Dupre B (2003) Chemical weathering in granitic environments. Chem Geol 202(3-4):225-256

Paul HJ, Gillis KM, Coggon RM, Teagle DAH (2006) ODP Site 1224: a missing link in the investigation of seafloor weathering. Geochem Geophys Geosyst 7(2):1-15

Pfeifer HR, Derro MH, Rey D, Schlegel C, Atteia O, Dalla Piazza R, Dubois JP, Mandia Y (2000) Natural trace element input to the soil-sediment-water plant system: examples of background and contaminated situations in Switzerland, Eastern France and Northern Italy. In: Marker B, Friese K (eds) Trace elementstheir distribution and effects in the environment. Elsevier, Amsterdam, pp 33-84

Plank T (2005) Constraints from thorium/lanthanum on sediment recycling at subduction zones and the evolution of the continents. J Petrol 46(5):921-944

Plank T, Langmuir CH (1998) The chemical composition of subducting sediment and its consequences for the crust and mantle. Chem Geol 145(3-4):325-394

Reymer A, Schubert G (1984) Phanerozoic addition rates to the continental-crust and crustal growth. Tectonics 3(1):63-77

Ricke W (1960) Ein Beitrag Zur Geochemie des Schwefels. Geochim Cosmochim Acta 21(1-2):35-80

Roelandt C, Godderis Y, Bonnet MP, Sondag F (2010) Coupled modeling of biospheric and chemical weathering processes at the continental scale. Glob Biogeochem Cycle 24:1-18

Roth J (1878) Flusswasser, Meerwasser, Steinsalz. Verlag von Carl Habel, Berlin

Roth J (1879) Allgemeine und Chemische Geologie, Erster BandBildung und Umbildung der Mineralien. Quell-, Fluss- und Meerwasser. Die Absätze. Verlag von Wilhelm Hertz (Bessersche Buchhandlung), Berlin

Roth J (1893) Allgemeine und Chemische Geologie, Dritter BandZweite Abteilung: Verwitterung, Zersetzung und Zerstörung der Gesteine. Verlag von Wilhelm Hertz (Bessersche Buchhandlung), Berlin

Rudnick RL (1995) Making continental-crust. Nature 378(6557): 571-578

Rudnick RL, Gao S (2003) Composition of the continental crust. In: Rudnick RL (ed) Treatise on geochemistry. Elsevier, Amsterdam, pp 1-64

Talbi E, Honnorez J (2003) Low-temperature alteration of mesozoic oceanic crust, ocean drilling program leg 185. Geochem Geophys Geosyst 4(5):1-21

Taylor SR (1964) Abundance of chemical elements in the continental crust-a new table. Geochim Cosmochim Acta 28:1273-1285

Taylor SR, Mclennan SM (1985) The continental crust: its composition and evolution. Blackwell, Oxford

Taylor SR, Mclennan SM (1995) The geochemical evolution of the continental-crust. Rev Geophys 33(2):241-265

Taylor SR, Mclennan SM, Mcculloch MT (1983) Geochemistry of loess, continental crustal composition and crustal model ages. Geochim Cosmochim Acta 47(11):1897-1905

Van der Weijden CH, Pacheco FAL (2003) Hydrochemistry, weathering and weathering rates on Madeira island. J Hydrol 283(1-4):122-145 
Wedepohl KH (1969) Handbook of geochemistry I. Springer, Berlin

Wedepohl KH (1995) The composition of the continental-crust. Geochim Cosmochim Acta 59(7):1217-1232

West AJ, Galy A, Bickle M (2005) Tectonic and climatic controls on silicate weathering. Earth Planet Sci Lett 235(1-2):211-228
White WM, Dupre B, Vidal P (1985) Isotope and trace-element geochemistry of sediments from the Barbados Ridge Demerara Plain Region, Atlantic-Ocean. Geochim Cosmochim Acta 49(9):1875-1886 